\title{
Building Resilience of Rural Communities in Wolaita through Sustainable Production, Value addition and Marketing of Traditional Crops
}

\author{
Derese Balcha *, Mathewos Chafa ${ }^{* *}$ \\ * MSC in economics, Wolaita Sodo University, Ethiopia \\ *** Msc rural development and planning, Wolaita Sodo University, Ethiopia \\ DOI: 10.29322/IJSRP.12.01.2022.p12126 \\ http://dx.doi.org/10.29322/IJSRP.12.01.2022.p12126
}

\begin{abstract}
The study was conducted in Boloso Sore, Damot Pulasa, Kindo Koyisha and Duguna Fango woredas of Wolaita zone to generate baseline data for the project "Building Resilience for rural communities in Wolaita through sustainable production, value addition and marketing of traditional crops" that could help monitoring of the project through the agreed indicators and to track progress against baseline situation. Data were generated from 300 households who were selected using systematic random sampling techniques and Key Informant Interview with zonal and woredas experts. The generated data were analyzed using descriptive statistics, Household Dietary Diversity Score, Food Insecurity Access Scale and narrations. The findings indicated that on average households were at active working age, average family size was 7 which are greater than the national average of 4.3 and the regional average of 4.9 ; more than 50 percent of households did not attend formal education, crop production was a dominant livelihood strategy and traditional crops were more market oriented than major crops produced. The findings also showed that traditional crops except ginger, taro and garlic were produced organically; no strategy, no plan and no taskforce established to promote traditional crops, Comprehensive strategy that takes into account income generating activities, nutritional diversification, mobilization of stakeholders to promote traditional crops, capacity building, closely working with beneficiaries, value addition on traditional crops to earn more and family planning are recommended to visualize impacts of the project at its lifespan.
\end{abstract}

\section{INTRODUCTION}

$\mathrm{T}$ erepeza Development Association (TDA) has been working in all woredas of Wolaita zone for 3 decades, since 1987, and has recently expanded its scope of intervention to other neighboring zones of Sothern Nations Nationalities and People Region (SNNPRS), especially Gurage, Hadiya, Silte, Kembata. TDA is currently reaching over 150,000 households with a total population of 900,000, with different strategic development pillars: Agriculture and Natural Resources Management, with due focus on climate smart agriculture techniques; Economic Development and Social Transformation through self-help groups promotion Send a Cow (SAC), was also implementing taro flour project in Wolaita zone where it worked with smallholder farmers who were poor and marginalized from society due to their poverty and social status.

The project brought some good lessons that taro flour production has proven to be a viable and replicable value chain process. Men and women worked together on an equal basis (gender equality promoted) developing rural agri-businesses where they were in control of all steps. The project made wide use of local resources and farmers, who were organized into cooperatives and contributed their labor and skills became full owners of the process which includes: peeling, washing, chopping, drying, grinding, packing, storing and marketing. The most important learning is that farmers can be excellent learners, innovators and business people, regardless of their level of poverty, literacy and education.

Wolaita zone is located in SNNPR of Ethiopia. Four districts such as Boloso Sore, Kindo Koysha, Duguna Fango and Damot Pulasa out of sixteen rural woredas were identified for implementation of the project as being food insecure and lacking income opportunities for poor rural communities. In these 4 woredas, 20 kebeles were selected for project implementation. The project intends to address underlying causes of vulnerability in target communities (hunger, poverty, lack of biodiversity) through promoting sustainable production, value addition and marketing of traditional crops. Traditional crops tend to be overlooked by agricultural development systems, which allocate more human and financial resources to the most common staple and commodity crops, furthering a lack of agricultural diversification and the use of unsustainable farm techniques including use of chemical fertilizers. Thus traditional crops are at risk of disappearing. 


\section{Objectives of the study}

General Objective is to increase resilience of rural communities in Wolaita through integrating climate- smart production, value addition and marketing of traditional crops in their agri-businesses.

1. To build capacity of smallholder farmers to integrate diversified and sustainable production systems focused on traditional crops into their farms;

2. To enable smallholder farmers to establish effective agribusinesses involving value addition and marketing of traditional crops,

3. To lobby local government and stakeholders to ensure that the widespread promotion of traditional crops is supported and institutionalized.

\section{PURPOSE}

The purpose of the assignment was to conduct a baseline assessment on impact and outcome indicators of the project and determine the present (2020) values, thereby supporting the project management team in determining their target values. Thus the availability of robust baseline data is believed to enable TDA and SAC to concretely monitor results through agreed indicators and to track progress against the baseline situation. The consultant, therefore, has organized the activities to collect reliable baseline data through an appropriate methodology which included formulation of data collection tools, measurement of baseline indicators, analysis of generated data and determination of values and verification of assumptions stipulated, especially in relation to outcome indicators. The main result achieved was quantitative and qualitative description of current situation of high-level indicators through detailed description of situation of each objectively verifiable indicator contained in the Logical Framework.

\section{Methodology}

\section{Description of study area}

The study was conducted in Wolaita zone which is located 330km south of Addis Ababa, the capital city of Ethiopia. The zone is located between $6.51-7.35 \mathrm{~N}$ and $37.23-38.14 \mathrm{E}$, latitude and longitude respectively. It covers a total area of 358,961.5ha and is composed of 16 rural woredas and 6 registered towns with total of 373 kebeles, among which 294 rural and 79 urban kebeles. The zone shares borders with Kembata Tembaro and Hadiya zones in the north, Oromia region in the northeast, Sidama region in the east, Gamo Gofa zone in the south and Dawuro zone in the south west. It comprises $12 \%$ of the population of southern region covering an area of 4,512 $\mathrm{km}^{2}$. The total population was 1,501,112 and it was projected to be 2,030,366 in 2017 (CSA, 2007). About 79.1\% and 20.9\% of the population is rural and urban with growth rate of 2.8\% and $4.8 \%$ respectively. It is classified into three agro-ecological zones; $56 \%$ Wayna-Dega/mid altitude, 35\% Kola/lowlands and 9\% Dega/high altitude. The mean annual rainfall ranges from $800 \mathrm{~mm}$ to $1,200 \mathrm{~mm}$. The rainfall is characterized by bimodal distribution pattern and the main rainy season/Meher/ is between June and September and Belg is from late February to late March/early April. The annual average temperature varies from $15.20^{\circ} \mathrm{C}$ to $31.10^{\circ} \mathrm{C}$. The altitude ranges from 1,200 to 2950 meters above sea level.

Out of the total 310,000 ha cultivated land, 5,318 ha is for grazing, 8,261 ha is covered by forests and bushes and 35,382.5 ha is cultivatable land (WZFEDD, 2017). Land shortage is an acute problem due to high population growth rate. Subsistence mixed croplivestock farming is the dominant farming system which is the main economic base. The major crops grown include maize, sweet potato, teff, coffee, enset, taro, haricot bean, chick pea, pea, wheat, barley and ginger. Crops such as maize, teff, sweet potato and enset are major cereals, roots and tuber crops grown and they occupy the largest proportion of cultivated land. Coffee, teff and Irish potato are grown mainly as cash crops. Maize also plays a vital role in cash generation activity. Farmers also keep animals such as oxen, cow, heifers, bulls, goat, sheep, donkey, horse and poultry chicken. Livestock contribute to the subsistence requirement of the population in terms of milk, milk products and meat. Livestock generates income, provides draught power, source of manure and means of transportation.

\section{Duguna Fango Woreda}

Duguna Fango Woreda has 36 rural kebeles and 5 rural towns with own municipalities. It constitutes three distinctive agro ecologies i.e. highlands, midlands and lowlands. The highlands are towards central part along Dugna Fango mountain chain and lowlands are towards northeast (Edo-Dendo) and east and south (Anka Bilate) areas. It is known for mixed farming where both crops and livestock farming are undertaken. Livestock farming is much smaller in highland areas due to limited access to grazing land as well as the area is heavily cultivated and land is much scarce. Crops are much diverse in highlands whereas lowland crops are limited due to moisture stress and grow annual field crops (Table 1). In highlands, climate is much favorable to grow diverse crops including a number of traditional crops, while types of traditional crops are less diverse in lowlands.

This publication is licensed under Creative Commons Attribution CC BY.

http://dx.doi.org/10.29322/IJSRP.12.01.2022.p12126

WWW.ijsrp.org 


\section{Damot Pulasa Woreda}

Damot Pulasa Woreda is located at the northern part of neighboring Hadiya and Kembatta zones. Agriculture, mainly crop farming, is the main livelihood activity of the community. The key challenge to agricultural production is water logging, soil degradation resulting in soil infertility and leaching. There are a number of common crops including some locally known as well as newly adopted ones (Table $2)$. It has midland agro ecology.

\section{Kindo Koyisha Woreda}

Kindo Koyisha Woreda is one of the lowlands of Wolaita zone and relatively drier as it is in the Omo river valley. There are highland communities in its southern part with escarpment towards the valley of Omo River. The topography is much of a steep slope with rugged terrain except few areas along Omo River, which is flat. Moisture stress is a key challenge in flat lowlands to grow different crops. In the meantime, in high and mid agro ecology, diversified crops are grown but land degradation due to erosion is a serious challenge. There are a number of locally grown crops but are being replaced by new crops due to less attention given (Table 3 ).

\section{Boloso Sore woreda}

Boloso Sore woreda is one of the largest woreda of Wolaita zone with large population and land area. It is mainly midland agroecology with moderate temperature and better rainfall. It is suitable to crop production; however, crop diversity is still low and much focus was given to synthetic fertilizer demanding crops. Enset, coffee, taro, potatoes, yam and fruits are the common crops grown. However, the government focused on production of Teff, Maize, and wheat and haricot bean with high artificial fertilizers demand and with high market value. In addition, Taro, Ginger, Potatoes, Frits mainly (mango and avocado) and Yam are also produced.

\section{Sampling techniques and sample size determination}

In collaboration with zonal government, TDA and Send a Cow identified 4 woredas namely Boloso Sore, Damote Pulasa, Duguna Fango and Kindo Koysha for project intervention. Within these woredas, 20 rural Kebeles such as Tadisa, Dola, Yukara, Gurumo Koyisha and Wormuma kebeles from Boloso Sore Woreda; Bibiso Olola, Zamine Wulisho, Olola, Galcha Suke and Waribira from Damot Pulasa Woreda; Duguna Kindo, Waraza Lasho, Duguna Shinka, Duguna Ofa Kalacha and Duguna Koyisha Humbo from Duguna Fango woreda; and Hanaze, Borkoshe, Zebato, Manera and Sere Finchawa from Kindo Koysha Woreda were identified (Table 5). Within these kebeles a total of 300 households were identified using systematic random sampling techniques. 
Table 1. Sample households

\begin{tabular}{lll}
\hline Woreda & Kebeles & Samples \\
\hline \multirow{4}{*}{ Boloso Sore } & Tadisa & 17 \\
& Dola & 14 \\
& Yukara & 15 \\
& GurumoKoysha & 15 \\
& Wormuma & 14 \\
& Bibiso Olola & 31 \\
& Zamine Wulisho & 14 \\
Daamote Pulasa & Olola & 6 \\
& Galcha Suke & 9 \\
& Waribira & 15 \\
& Duguna Kindo & 18 \\
& Waraza Lasho & 13 \\
& Duguna Shinka & 13 \\
& Duguna Ofa Kalacha & 15 \\
& Duguna Koysha Humbo & 17 \\
& Hanaze & 15 \\
& Borkoshe & 15 \\
& Zebato & 10 \\
& Manera & 20 \\
& Sere Finchawa & 14 \\
\hline & Total & $\mathbf{3 0 0}$ \\
\hline
\end{tabular}

\section{Methods of data collection}

Standardized structured and semi-structured questionnaire were developed by consulting firm and sent to staffs of TDA for comments and suggestions. After incorporating their comments and suggestions, final questionnaire was developed. Training and briefing on the questionnaire was made to staffs of TDA and enumerators and their supervisors. Then pre-testing was conducted to validate the questionnaire and make corrections for vague sentences and words. Then final version of the questionnaire was printed and data collection was conducted. Data were collected for 8 days from $1^{\text {st }}-8^{\text {th }}$ March 2021 from rural households from selected kebeles with close supervision. On field edition of filled questionnaire was done by two senior experts from consulting team. The collected data was inputted to Excel and then transported to STATA software. In addition to survey data, Key Informant Interviews were conducted with zonal agricultural and natural resource department experts and four woreda agricultural department staffs. Moreover, secondary data were collected from Wolaita zone, woredas and reports and publications.

\section{Methods of data analysis}

The survey data were analyzed mainly using descriptive statistics such as mean, maximum, minimum, frequencies and percentages. In addition, Household Dietary Diversity Score and Food Insecurity Access Scale as analytical tools were used to score household dietary diversity and to determine household food insecurity status. It considered average number of different food groups consumed by households over the past 24 hours. Qualitative data collected from woredas and zonal agricultural and productive safety net offices were summarized using narration analytical method. The results were summarized using tables for vividness. 


\section{RESUlts AND Discussion}

\section{Age of households}

The mean age of sampled households was 42.76 years indicating that the households are at active working age. However, the maximum age was 80 years and the minimum age was 25 years. About $52.3 \%$ of sampled households had children under age six and all households had active working force in the age category between 15 and 65 years (Table 6). Thus the age category between 15 and 65 years composed of $53.9 \%$ of the total population with dependency ratio of $85 \%$. According to Central Intelligence Agency report the dependency ratio of Ethiopia for the 2020 was $76.8 \%$ (CIA, 2020). This implies that each working age has to feed one non-working age. The dependency ratio is a measure of the number of dependents aged zero to 14 and over the age of 65 , compared with the total population aged 15 to 65 . This demographic indicator gives insight into the number of people of non-working age, compared with the number of people of working age.

Table 2. Age cohort of sampled households

\begin{tabular}{lllll}
\hline Age category (years) & N & Percent & Number & Percent of total household size \\
\hline 1-5 years & 157 & 52.3 & 225 & 10.6 \\
6-14 years & 265 & 88.3 & 732 & 34.7 \\
15- 65years & 300 & 100 & 1136 & 53.9 \\
$65^{+}$ & 10 & 3.3 & 12 & 0.5 \\
\hline Total & & & $\mathbf{2 1 0 6}$ & $\mathbf{9 9 . 7}$
\end{tabular}

Note: $\mathrm{N}$ represents the number of households who have household members in the given age category. A household can have household member in each of the category and thus there is a possibility of being counted as counting is not exclusive.

\section{Family size and religion of households}

The mean family size of sampled households was 7 with maximum of 12 and minimum of 2 . The average family size of southern nation nationalities and people regional state is 4.9 persons per household (CSA, 2007). Compared with regional average, sample households have more family size per household indicating that family planning is much more required to maintain family size with available resources for at least sustenance. About $98 \%$ of sampled households have corrugated iron sheet roofed houses. About 85 percent of sampled households are protestant religion followers, 11 percent are Orthodox religion followers and the remaining are catholic religion followers.

\section{Sex and marital status of households}

Households are designated as either male-headed or female headed based on the norm, a pattern consistent with traditional family structures and views on gender roles and their perceived relative economic importance (FAO and UNDP, 2002). Being head of a household gives a person power to make decision over key production resources. About 81.3 percent of sampled households were headed by male headed households and the remaining 18.7 percent was headed by female headed households. About 72 percent of sampled households were married whereas 16 percent were single (Table 7).

Table 3. Sex and marital status of household

\begin{tabular}{lll}
\hline Marital status & Frequency & Percent \\
\hline Marriage & 216 & 72 \\
Single & 48 & 16 \\
Widow & 25 & 8.3
\end{tabular}

This publication is licensed under Creative Commons Attribution CC BY. 


\begin{tabular}{lll} 
Divorced & 11 & 3.7 \\
\hline Total & $\mathbf{3 0 0}$ & $\mathbf{1 0 0}$ \\
\hline Sex of household head & & \\
\hline Male & 244 & 81.3 \\
Female & 56 & 18.7 \\
\hline Total & $\mathbf{3 0 0}$ & $\mathbf{1 0 0}$ \\
\hline
\end{tabular}

\section{Education level of households}

Education is important to the improvement of agricultural productivity; formal education opens the mind of a farmer to knowledge, non-formal education gives a farmer hands-on training and better methods of farming and informal education keeps a farmer abreast with changing innovations and ideas and allows a farmer to share experience gained (Oduro-Ofori Eric et al, 2014). About 49.7 percent of sampled households did not attend formal education; of which 22.7 percent can read and write. However, 47.3 percent of sampled households attended formal education up to grade 12. Only 3 percent had either diploma or degree (Table 8). This implies that almost half of the sampled households have very low level of education calling for close follow up and supervision for the success of the project.

Table 4. Educational status of households

\begin{tabular}{lll}
\hline Education level & Frequency & Percent \\
\hline Illiterate & 81 & 27 \\
Read and write & 68 & 22.7 \\
Grade1 -8 level & 101 & 33.7 \\
Grade 9-12 level & 41 & 13.6 \\
Diploma & 8 & 2.7 \\
Degree & 1 & 0.3 \\
\hline Total & $\mathbf{1 0 0}$ & $\mathbf{1 0 0 \%}$ \\
\hline
\end{tabular}

\section{Land holding size 2019/2020}

Land is one of the most important production resources which can be owned or rented/shared by households. Households in rural areas use land for varying purposes. Land use concerns the products and/or benefits obtained from use of the land as well as land management actions/activities carried out by humans to produce those products and benefits (FAO, 1999). The households on average owned 0.53ha of land and rented out on average 0.005 ha with average shared out of $0.006 \mathrm{ha}$ (Table 9 ). They used these land holdings for crop production which accounted for 93 percent of land use indicating that the main livelihood of households was crop production.

Table 5. Land use practices of households

\begin{tabular}{lllll}
\hline No & Categories of land holdings & Mean owned land (ha) & Mean rented out (ha) & Mean shared out (ha) \\
\hline 1 & Crop production & $0.49(93 \%)$ & 0.003 & 0.006 \\
2 & Pasture and free grazing & 0.001 & - & - \\
3 & Vicinity of the house & 0.002 & - & -
\end{tabular}

This publication is licensed under Creative Commons Attribution CC BY. 


\begin{tabular}{lllll}
4 & Forest/plantation area & 0.033 & 0.002 & - \\
5 & Fallow land & 0.0004 & - & 0.006 \\
\hline & Average (ha) & 0.5264 & 0.005 & 0.006 \\
\hline
\end{tabular}

This publication is licensed under Creative Commons Attribution CC BY. 


\section{Livestock holdings in 2019/2020}

Livestock play very important economic and socio-cultural roles for the wellbeing of rural households, such as food supply, source of income, asset saving, source of employment, soil fertility, livelihoods, transport, agricultural traction, agricultural diversification and sustainable agricultural production (Mario Herrero et al, 2012). Even though livestock production is not as dominant as crop production, sampled households owned some portion of livestock (Table 10). The study findings indicated that sampled households entirely owned local breeds and access to cross breeds was very much limited. It is very hard to boost milk production in the absence of cross breed cows which give almost 6-7 times milk production as compared to local breeds. Milk is a complete nutritious food for proper growth and development of children.

Table 6. Livestock holdings of households

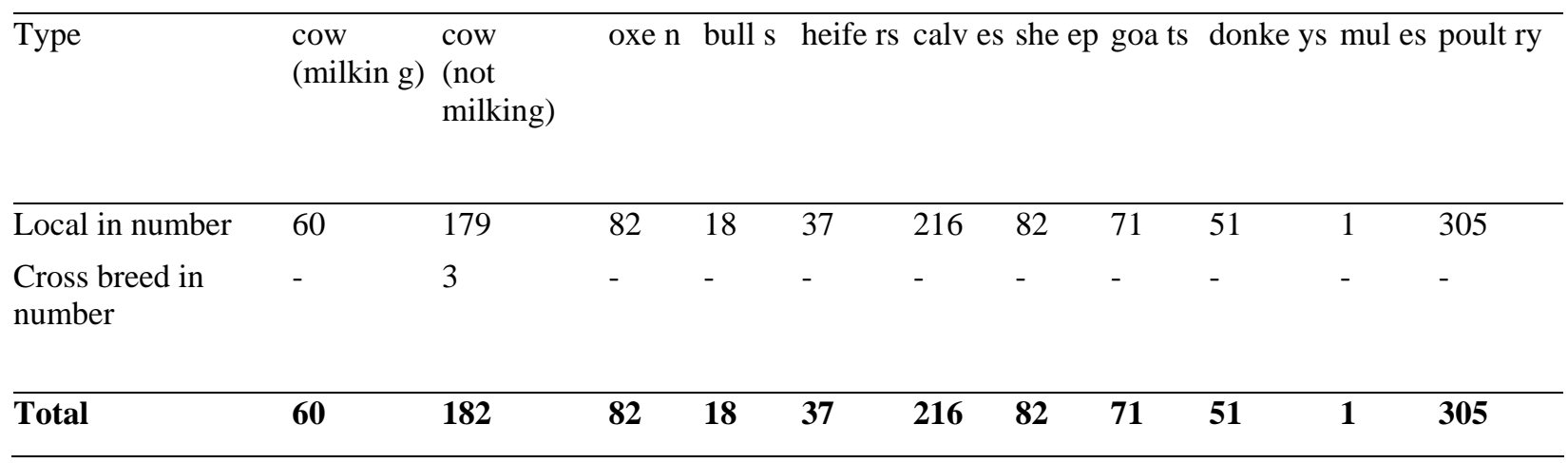

\section{Household income}

Generally households in rural areas generate income from two main sources such as farm income and non-farm income. Farm income refers to the money generated by farm or agribusiness operations. This can also have farming income and on-farm income. Farming income can be generated from crop production, livestock rising, poultry rising dairy farming, among others. On-farm income can be generated while farmers are hired as daily labor on farm activities of other farmers, engaged in fattening activities, among others. Off-farm (non-farm) income refers to the portion of farm household income obtained off the farm, including non-farm wages and salaries, pensions, and interest income earned by farm families (Wikipedia, the free encyclopedia). The largest share (76.2\%) of households' income came from farming activities and the smallest share (7.1\%) was obtained from off-farm or non-farm income sources (Table 6). This indicates that income from off-farm activities to supplement the livelihood of households was very small and needs further strengthening.

Table 6. Income of households for 2019/2020

\begin{tabular}{llll}
\hline Type & Farming & Off farm & On farm \\
\hline Income sources & $\square$ & $\square$ & $\square$ \\
Mean annual income (Birr) & $3653.5(76.2 \%)$ & $343.73(7.1 \%)$ & $802.03(16.7 \%)$ \\
\hline
\end{tabular}

The details of income sources of households were also depicted (Table 6). The table also compares income obtained in two consecutive years. Almost all households reported that their income had shown increment as compared to previous year except for vegetables and livestock rearing. All of them said that these various income generating activities were not new to them as they have engaged in them for years. All of them reported that there was increase in quantity of supply but no value addition to meet consumer preference and fetch better price. 


\section{Table 7. Sources of household income}

\begin{tabular}{|c|c|c|c|c|c|}
\hline $\begin{array}{l}\text { Type of } \\
\text { sold in } t\end{array}$ & $\begin{array}{l}\text { agriculture comm } \\
12 \text { months' time }\end{array}$ & $\begin{array}{l}\text { yAverage income } \\
\text { current earned (birr) }\end{array}$ & $\begin{array}{l}\text { ofAverage income } \\
\text { previous year (Birr) }\end{array}$ & $\begin{array}{l}\text { of0 }=\text { Decreas } \\
1=\text { Increas } \\
\text { e }\end{array}$ & \multirow[t]{2}{*}{$\begin{array}{l}\text { eIs the business new or existing? } \\
\mathrm{O}=\text { Existing } 1=\text { new }\end{array}$} \\
\hline 3.3 .2 .1 & Cereals & 1278.72 & 1198.74 & $1=132$ & \\
\hline 3.3.2.2 & Fruits & 182.67 & 171.25 & $1=16$ & $0=55$ \\
\hline 3.3.2.3 & Roots & 584.56 & 348.00 & $1=63$ & $0=61$ \\
\hline 3.3.2.4 & Other cash crops & 292.28 & 274.00 & $1=37$ & $0=25$ \\
\hline 3.3.2.5 & Vegetables & 73.07 & 102.75 & $0=29$ & $0=17$ \\
\hline 3.3.2.6 & Cattle & 328.81 & 308.25 & $1=71$ & $0=67$ \\
\hline 3.3 .2 .7 & Sheep/goat & 548.02 & 479.50 & $1=43$ & $0=19$ \\
\hline 3.3.2.8 & Chicken & 365.35 & 342.50 & $1=92$ & $0=41$ \\
\hline
\end{tabular}


Other agricultural income generating activities practiced in the 12 months' time

\begin{tabular}{|c|c|c|c|c|c|}
\hline 3.3 .1 & Grain trade & 506.02 & 431.40 & $1=163$ & 038 \\
\hline 3.3 .2 & Livestock fattening & 578.71 & 647.10 & $1=96$ & 1 \\
\hline 3.3.3 & Vegetable and fruit trading & 361.44 & 359.5 & $1-33$ & \\
\hline
\end{tabular}

\begin{tabular}{|c|c|c|c|}
\hline What changes made to the agricultural commodity produced and sold in the last 7Response & $\begin{array}{l}\text { anges made to the agricultural commodity produced and sold in } \\
\text { time? }\end{array}$ & $\begin{array}{l}\text { 7Response } \\
\text { Yes/No }\end{array}$ & $\begin{array}{l}\text { Price due to the added practice } \\
0=\text { increase } \\
1=\text { decrease }\end{array}$ \\
\hline 1 & Increase in volume of sale & Yes $=300$ & $0=203$ \\
\hline 2 & Graded for different price and different buyers & $\mathrm{No}=300$ & $1=15$ \\
\hline 3 & Reduced the loss due to improved transportation. & $\mathrm{No}=300$ & $1=27$ \\
\hline 4 & $\begin{array}{l}\text { Sold in semi processed status to reduce spoilage and easier for } \\
\text { consumers/transporters }\end{array}$ & $\mathrm{No}=300$ & $1=3$ \\
\hline 5 & Increased the storage time without spoiling. & $\mathrm{No}=300$ & $1=0$ \\
\hline 6 & Improved the package for better handling and preservation. & $\mathrm{No}=300$ & $1=0$ \\
\hline
\end{tabular}

\section{Crop production in 2019/2020 cropping season}

Crop production was the dominant activity and on average 0.472ha of land was covered by various crops in the year 2019/2020. The largest share was taken by maize and the least was occupied by mango plant (Table 8). Cereal crop such as maize, sorghum, barley, wheat and teff accounted $71.6 \%$ of the total crops grown. The mean yield obtained was $994.67 \mathrm{~kg}$ of which 63 percent was home consumed and 33.6 percent was sold to the market.

Table 8. 2019/2020 crop production of households

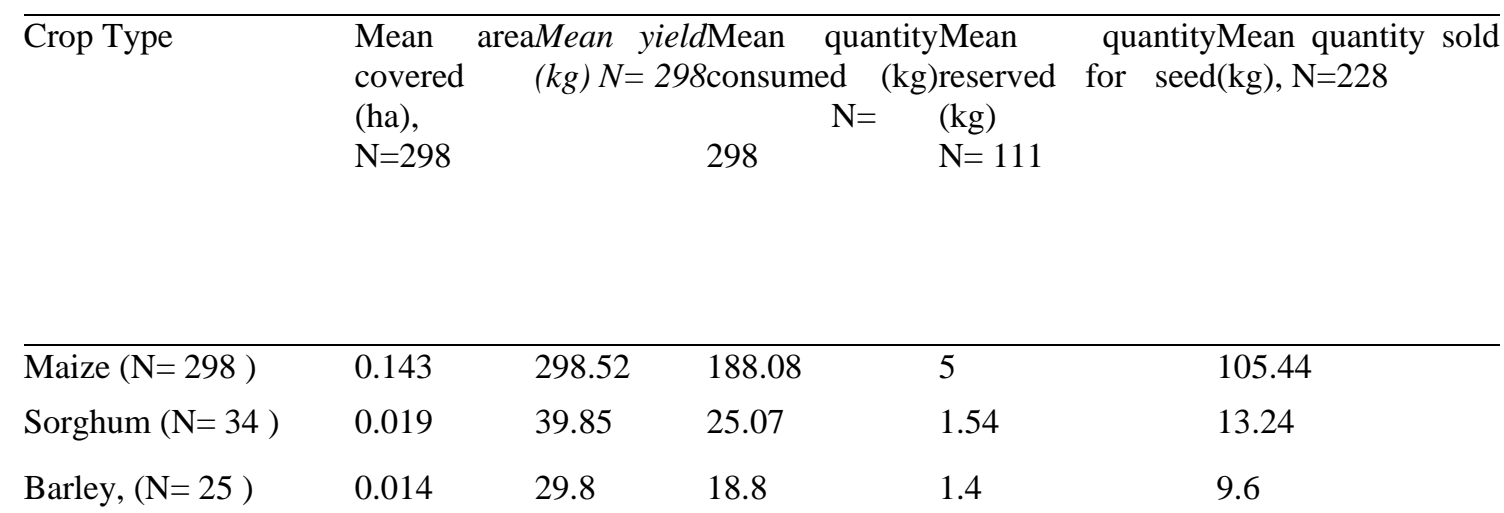




\begin{tabular}{|c|c|c|c|c|c|}
\hline Wheat, $(\mathrm{N}=62)$ & 0.019 & 39.8 & 25.07 & 2.1 & 12.63 \\
\hline Teff $(\mathrm{N}=182)$ & 0.071 & 149.2 & 94.04 & 4.3 & 50.86 \\
\hline Haricot $(\mathrm{N}=279)$ & 0.076 & 159.2 & 100 & 6.4 & 52.8 \\
\hline Beans $(\mathrm{N}=51)$ & 0.014 & 29.8 & 18.8 & 4.9 & 6.1 \\
\hline Peas $(\mathrm{N}=44)$ & 0.009 & 19.9 & 12.5 & 0.2 & 7.2 \\
\hline Enset $(\mathrm{N}=234)$ & 0.014 & 29.8 & 18.8 & 0.9 & 10.1 \\
\hline Potato $(\mathrm{N}=131)$ & 0.019 & 39.8 & 25.07 & 1.5 & 13.23 \\
\hline $\begin{array}{l}\text { Improved Taro } \\
(\mathrm{N}=150)\end{array}$ & 0.033 & 69.6 & 43.8 & 2.3 & 23.5 \\
\hline Coffee $(\mathrm{N}=285)$ & 0.012 & 26.8 & 16.9 & 2 & 7.9 \\
\hline $\begin{array}{l}\text { Avocado }(\mathrm{N}=129 \\
\text { ) }\end{array}$ & 0.007 & 14.9 & 9.4 & 0.4 & 5.1 \\
\hline Mango (N=108) & 0.008 & 17.9 & 11.2 & 0.61 & 6.09 \\
\hline Banana $(\mathrm{N}=127)$ & 0.014 & 29.8 & 18.8 & 0.72 & 10.28 \\
\hline Average & 0.472 & 994.67 & $626.33(63)$ & $34.27(3.4 \%)$ & $334.07(33.6 \%)$ \\
\hline
\end{tabular}




\section{Traditional crop production in 2019/20 cropping season}

Area covered, yield, consumed, reserved and sold of traditional crops

In addition to major crops production as given in Table 8 above, 70.3 percent of households were engaged in production of traditional crops (Table 14). The total area covered by traditional crops was $0.088 \mathrm{ha}$ and the total production was $194.8 \mathrm{~kg}$ of which 71 percent was home consumed and 38.3 percent was sold to the market.

\section{Table 9. Traditional crops production}

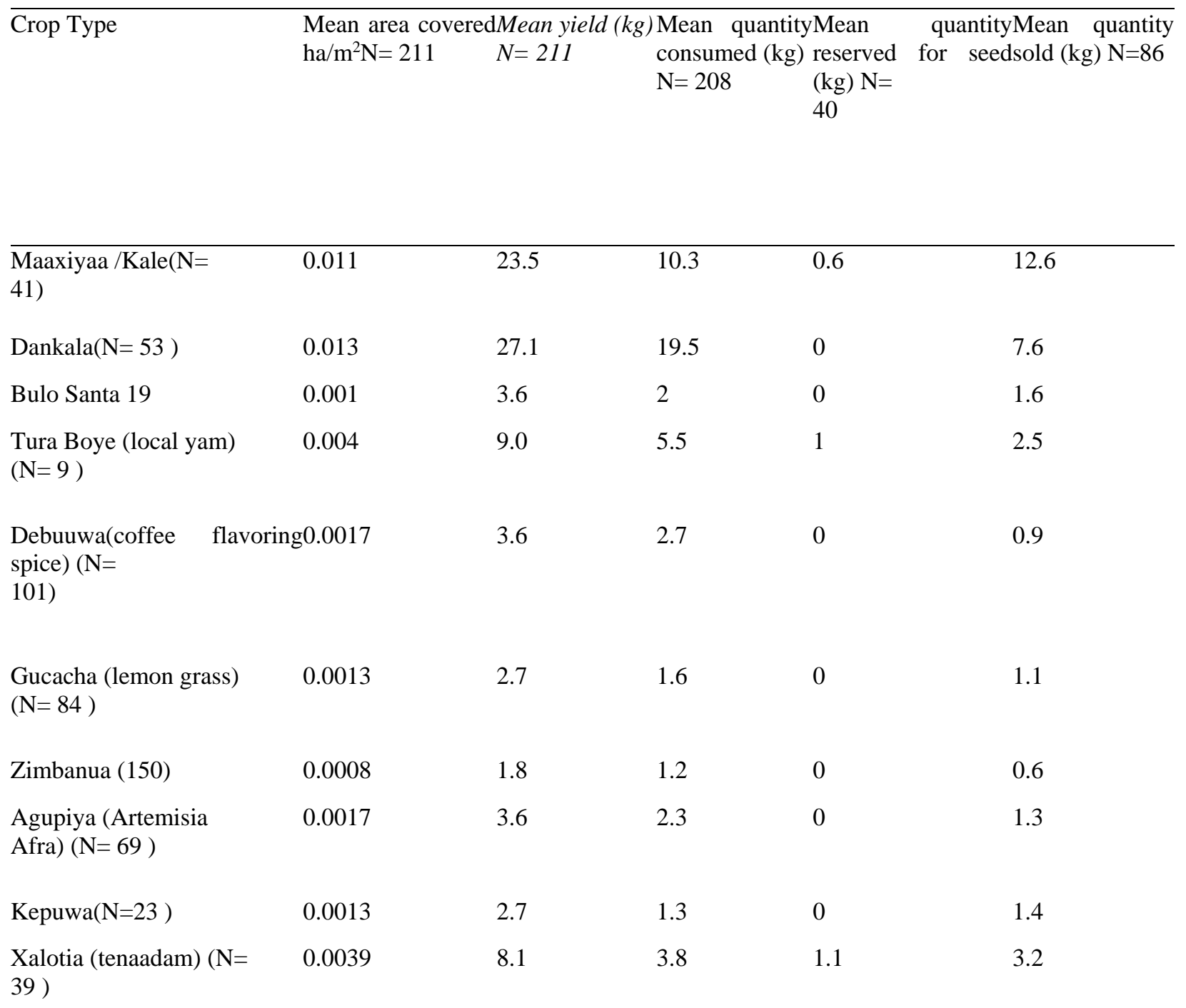




\begin{tabular}{llllll} 
(Natira) Ariti $(\mathrm{N}=18)$ & 0.0052 & 10.8 & 5.8 & 1.2 & 3.8 \\
Katikala(N=14) & 0.006 & 12.6 & 8.8 & 0 & 3.8 \\
$\begin{array}{l}\text { Tumuwa /garlic (N=53 } \\
\text { ) }\end{array}$ & 0.007 & 14.1 & 6 & 2 & 6.1 \\
$\begin{array}{l}\text { Yenjello/ Ginger (N= } \\
29)\end{array}$ & 0.0072 & 14.5 & 5.2 & 1.9 & 7.4 \\
Local Taro (N=41) & $\mathbf{0 . 0 2 7 ( 3 0 . 6 8 \% )}$ & $57.1(29.3 \%)$ & 23.1 & 13.3 & 20.7 \\
\hline Average & $\mathbf{0 . 0 8 8}$ & $\mathbf{1 9 4 . 8}$ & $\mathbf{1 3 8 . 4 ( 7 1 \% )}$ & $\mathbf{2 0 . 1 ( 1 0 . 3 \% )}$ & $\mathbf{7 4 . 6 ( 3 8 . 3 \% )}$ \\
\hline
\end{tabular}

\section{Input use for traditional crops in 2019/20 cropping season}

Households used various inputs to produce traditional crops. Almost all sampled households did not use irrigation, fertilizer and pesticide to produce traditional crops as sole crop except for garlic, ginger and local taro (Table 9). This indicates that households rely completely on rain for their traditional crop production. However, it is possible to produce most of these traditional crops using ground water during dry season. Some farmers used Urea and DAP fertilizers to produce local taro traditional crop. However, all households used manure or compost to produce traditional crops. This shows that traditional crops produced by households are organic in nature calling for further interventions to promote sustainable agriculture.

Table 10. Input uses for traditional crops

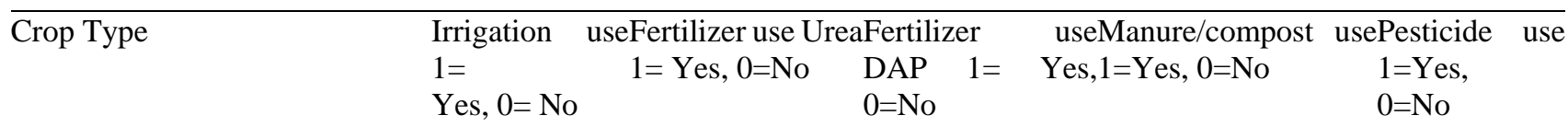

\begin{tabular}{|c|c|c|c|c|c|}
\hline Maaxiyaa /Kale & $0=37$ & $0=31$ & $0=21$ & $0=14$ & $0=11$ \\
\hline Dankala & $0=25$ & $0=15$ & $0=33$ & $0=11$ & $0=9$ \\
\hline Bulo Santa & $0=0$ & $0=5$ & $0=31$ & $0=12$ & $0=6$ \\
\hline $\begin{array}{l}\text { BangaKolto (white tuber } \\
\text { crop) }\end{array}$ & $0=0$ & $0=4$ & $0=22$ & $0=4$ & $0=4$ \\
\hline Tura Boye (local yam) & $0=19$ & $0=22$ & $0=13$ & $0=10$ & $0=5$ \\
\hline $\begin{array}{l}\text { GezeDono } \\
\text { hairy potato) }\end{array}$ & $0=34$ & $0=13$ & $0=6$ & $0=8$ & $0=3$ \\
\hline $\begin{array}{l}\text { Debuuwa(coffee flavoring } \\
\text { spice ) }\end{array}$ & $0=6$ & $0=39$ & $0=23$ & $0=5$ & $0=5$ \\
\hline Gucacha (lemon grass) & $0=18$ & $0=55$ & $0=28$ & $0=2$ & $0=2$ \\
\hline Zimbanua & $0=6$ & $0=63$ & $0=1$ & $0=3$ & $0=4$ \\
\hline
\end{tabular}




$\begin{array}{llllll}\begin{array}{l}\text { Karetasawuwa (Black } \\ \text { Cumin) }\end{array} & 0=0 & 0=5 & 0=11 & 0=9 & 0=7 \\ \begin{array}{l}\text { Botasawuwa(White } \\ \text { Cumin) }\end{array} & 0=0 & 0=2 & 0=21 & 0=4 & 0=4 \\ \text { Agupiya (Artemisia Afra) } & 0=1 & 0=1 & 0=15 & 0=3 & 0=3 \\ \text { Kepuwa } & 0=5 & 0=2 & 0=29 & 0=1 & 0=7 \\ \text { Xalotia (tenaadam) } & 0=7 & 0=5 & 0=8 & 0=4 & 0=4 \\ \text { (Natira) Ariti } & 0=5 & 0=1 & 0=1 & 0=2 & 0=2 \\ \text { Katikala } & 0=0 & 0=0 & 0=2 & 0=5 & 0=1 \\ \text { Tumuwa /garlic } & 1=7 & 1=2 & 1=3 & 1=61 & 1=0 \\ \text { Yenjello/ Ginger } & 1=11 & 1=11 & 1=39 & 1=77 & 1=26 \\ \text { Local Taro } & 1=113 & 1=34 & 1=21 & 1=201 & 1=201 \\ \end{array}$




\section{Conservation practices for traditional crops}

Conservation agriculture is defined as a concept for resource-saving agricultural crop production that strives to achieve acceptable profits together with high and sustained production levels while concurrently conserving the environment (FAO, 2006). Only 65 farmers, $(21.66 \%)$ reported that they have knowledge of practicing some sustainable farming techniques, especially mulching, composting and intercropping, which is $3.33 \%, 10 \%$ and $8.33 \%$ respectively (Table 16). However, no respondent reported that they practice minimum tillage, cover crop and crop rotation. Some households used combination of conservation practices; the dominant one was combination of mulching, intercropping and crop rotation. Households who practiced these techniques mentioned lack of awareness, lack of training, burning of crop residues, etc. as challenges and suggested capacity building as one of the alternatives to overcome challenges of sustainable farming practices.

Table 11. Sustainable farming practices of households

\begin{tabular}{lll}
\hline Conservation practice for traditional crops & Frequency & Percent \\
\hline Mulching & 10 & 3.33 \\
Cover crop & 0 & 0 \\
Compost & 30 & 10 \\
Intercropping & 25 & 8.33 \\
Crop rotation & 0 & 0 \\
& & \\
\hline Total & $\mathbf{6 5}$ & $\mathbf{2 1 . 6 6}$ \\
\hline
\end{tabular}

\section{Marketing and value addition of traditional crops}

About 81.7 percent of households did not engage in value addition whereas 18.3 percent engaged in adding values to some traditional crops (Table 11). In the process of adding values to ginger, farmers wash row ginger and then dry on the sun. They then produce powder after crashing the well dried ginger. Then 250 gram ginger powder was packaged and each gram was sold 50 birr because of value addition. On contrary, farmers sell $1 \mathrm{~kg}$ row ginger by 20 birr without value addition. Local taro was also value added by washing, polishing, and packaging into small quality of different kilograms and sold along main road to Addis Ababa and Dawuro. Value addition is the process of changing the product's value by changing its current place, time and form utilityto characteristics more preferred in the marketplace (https://www.herald.co.zw/value-addition-strategies). One of the value addition activities practiced was storing products for longer period of time binging time utility. Depending on agroecology of households, taro and other crops were stored for 1 to 2 months by 24 percent, $2-4$ months by 18.3 percent and above 4 months by 10.3 percent of households. Spoilage (18\%) and insects and pest infestation $(27.7 \%)$ were challenges forwarded by some households in storing taro and other traditional crops. About 56 percent of households used sack as packaging material in the course marketing traditional crops.

Table 12. Value addition practices for traditional crops

Value addition traditional
crops

\begin{tabular}{lll}
\hline $\begin{array}{l}\text { Ginger (Bolosso Sore woreda41 } \\
\text { cooperative member households) }\end{array}$ & 13.7 & $\begin{array}{l}\text { Dry the product then changeGinger powder } \\
\text { in to powder }\end{array}$
\end{tabular}

This publication is licensed under Creative Commons Attribution CC BY. 
Local taro (Kindo Koyish woreda14 packaging different kilogram)
4.6

$\begin{aligned} & \text { Packaging into differentPackaged in different } \\ & \text { kilogram }\end{aligned}$
kilogram

\begin{tabular}{lrr}
\hline Total & 55 & 18.3
\end{tabular}

\section{Transportation mechanism for traditional crops marketing}

Transportation results in the movement of goods from one place to another place thus making the product available through the customer at the right time. There can be various modes of transport or transportation. About 58.7 percent of households used women back for transporting traditional crops to markets followed by donkey. A very few households used mule and other transportation means (Table 13). Other source of transportation used was Bajaj motor.

Table 13. Transportation means of traditional crops marketing

\begin{tabular}{lll}
\hline Transportation means & Frequency & Percent \\
\hline Carry back & 176 & 58.7 \\
Donkey & 121 & 40.3 \\
Mule & 1 & 0.3 \\
Other & 2 & 0.7 \\
\hline Total & $\mathbf{3 0 0}$ & $\mathbf{1 0 0 \%}$ \\
\hline
\end{tabular}

\section{Marketing location of traditional crops}

Marketing is the sum of activities involved in directing the flow of goods and services from producers to consumers (https://www.britannica.com/topic/marketing). About $36 \%$ of households who produce traditional crops sold portion of their produces to markets. A traditional crop market is the economic marketplace where final goods or services are traded. It is not limited by a physical location since it refers to the commercial environment of a given economic system. About 60.3 percent of households sod their traditional crops products at local market. The remaining 36 percent and 3.7 percent sold at farm gate and large market, respectively (Figure 1). 


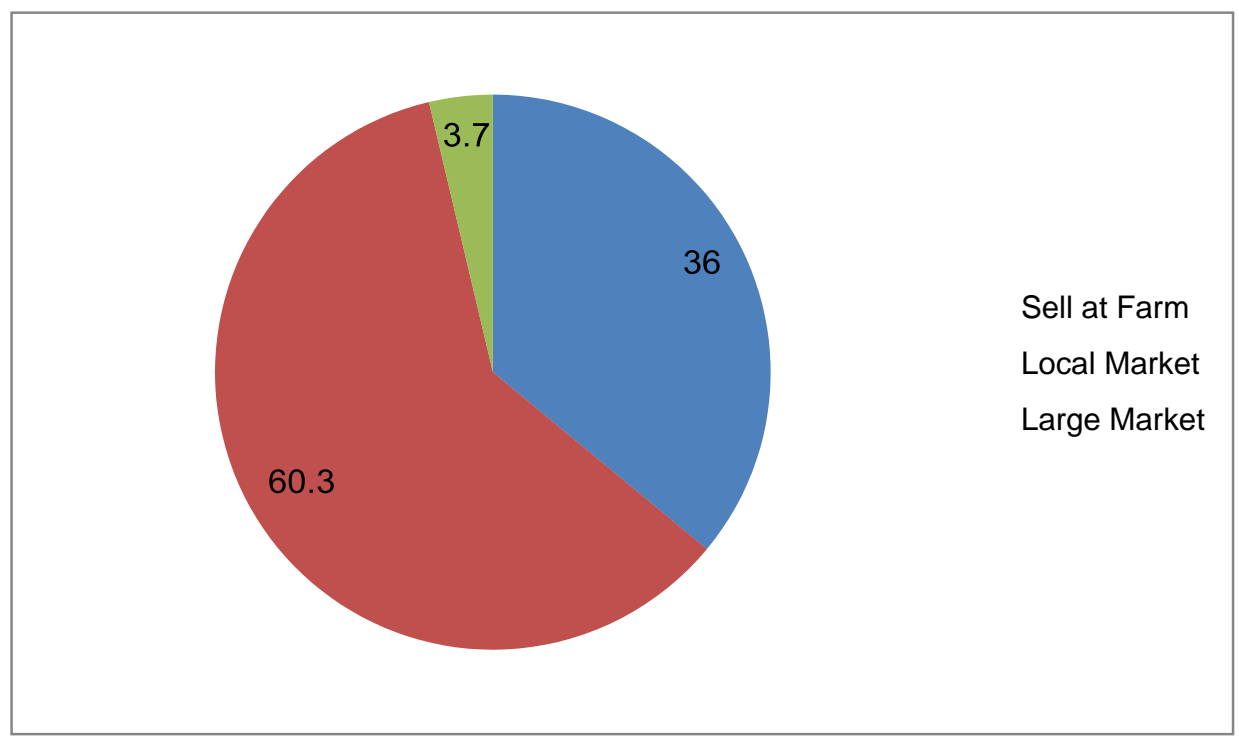

This publication is licensed under Creative Commons Attribution CC BY. 


\section{Extension services for traditional crops}

The discussion finding revealed that traditional crops were less focused and the intention of the government was to increase productivity of major crops that use fertilizers. This is mainly related to the need to meet the growing food need of large and ever growing population and the government is pushing for high production despite losing traditional crops while making environment unpleasant. Generally there were no strategy, no plan for future promotion and no taskforce establish to promote traditional crops at zonal level. Catering extension services to rural farmers is nowadays a common activity in most countries of the world to bring about economic change in rural areas (Anaeto et al., 2012). About 11.3 percent of households received extension services regarding production, marketing, value additional, packaging and consumption of traditional crops (Table 14). Even though many traditional crops are not prioritized under extension services, some crops such as taro get support as the crop has promotion of improved Bereket-1 variety. Therefore, farmers who were producing traditional taro crop received extension advice in the meantime as extension agents were providing support to improved taro variety. The extension services received for traditional crops include skill training such as block preparation, land preparation, spacing and marketing.

Table 14. Extension service of households

\begin{tabular}{lll}
\hline Extension service received & Frequency & Percent \\
\hline Yes & 34 & 11.3 \\
No & 266 & 88.7 \\
\hline Total & $\mathbf{3 0 0}$ & $\mathbf{1 0 0 \%}$ \\
\hline
\end{tabular}




\section{Access to training for traditional crops}

Rural communities need holistic support to transform their agrarian based economy. Training is required to capacitate rural community with self-employment skills, adopting agricultural technologies and new practices, searching for timely and reliable information, among others. About 96.7 percent of households did not receive any training related to production, marketing, value addition, packaging and consumption of traditional crops (Table 15). The type of training received was skill training using plot demonstration.

Table 15. Access to training

\begin{tabular}{lll}
\hline Training received & Frequency & Percent \\
\hline Yes & 10 & 3.3 \\
No & 290 & 96.7 \\
\hline Total & $\mathbf{3 0 0}$ & $\mathbf{1 0 0 \%}$ \\
\hline
\end{tabular}

\section{Credit services for traditional crops production}

Access to credit services is essential for sustainable agricultural development. It is needed for farming activities such purchase of improved seeds, fertilizer, pesticides, for family and consumption expenses. Almost all households did not receive credit from any of financial institutions for production, marketing, value addition, packaging and consumption of traditional crops (Table 16). The one who received the credit go it from saving cooperative establishing by particular nongovernmental organization.

Table 16. Credit access for traditional crops

\begin{tabular}{lll}
\hline Credit services & Frequency & Percent \\
\hline Yes & 1 & 0.3 \\
No & 299 & 99.7 \\
\hline Total & $\mathbf{3 0 0}$ & $\mathbf{1 0 0 \%}$ \\
\hline
\end{tabular}




\section{Participation in farmer field schools or farmer groups}

Participation in farmer research group, farmer field school and other farmer organization is believed to enhance leadership and management skills of individuals. It is also one source of information related to market prices of commodities. Farmer research group is one of the participatory agricultural research approaches aimed to improve the conventional top-down research approach that doesn't fully address the needs of subsistence and smallholder farmer (Yazie Chanie et al, 2014). In a typical farmer field school a group of 2025 farmers meets once a week in a local field setting and under the guidance of a trained facilitator (http://www.fao.org/agriculture/ippm/programme/ffs-approach/en/). In groups of five they observe and compare two plots over the course of an entire cropping season. One plot follows local conventional methods while the other is used to experiment with what could be considered "best practices". They experiment with and observe key elements of the agro-ecosystem by measuring plant development, taking samples of insects, weeds and diseased plants, and constructing simple cage experiments or comparing characteristics of different soils. At the end of the weekly meeting they present their findings in a plenary session, followed by discussion and planning for the coming weeks. However, almost all households ( 94.4 percent) did not participate in any one of the farmers organizations available in their areas (Table 17). Those who participated said that it has enhanced their productivity, developed cooperation spirit and support during hardships.

Table 17. Participation in farmer groups

\begin{tabular}{lll}
\hline Participation in farmer group & Frequency & Percent \\
\hline Yes & 17 & 5.6 \\
No & 283 & 94.4 \\
\hline Total & & \\
\hline
\end{tabular}




\section{Food consumption practices}

Total number of households consumed different types of food within 24 hours' time was 1767 which was divided by 300 households and yielded on average 5.99. The highest type of food consumed was cereals $(89.33 \%)$ and the lowest were fish $(0.66 \%)$ and organic meat $(0.66 \%)$ (Table 18). The average figure of the household dietary diversity for the target area was 5.99 food types within 24 hours as these also included food additives including oil, beverage and other kind of food, which are not standalone foods. This figure is resulted from the survey and does not have a threshold and thus changes can be measured from this baseline for the future progress and achievement of the project.

Table 18. Food categories consumed in the last 24 hours

\begin{tabular}{|c|c|c|c|c|}
\hline$\overline{\text { No }}$ & Types of food consume & the last 24 hours & Frequency & Percent \\
\hline 1 & Cereals & Yes & 268 & 89.33 \\
\hline 2 & Roots and tube crops & Yes & 266 & 88.66 \\
\hline 3 & Vitamin and vegetables & Yes & 106 & 35.33 \\
\hline 4 & Green vegetables & Yes & 76 & 25.33 \\
\hline 5 & Other vegetables & Yes & 109 & 36.33 \\
\hline 6 & Vitamin and fruits & Yes & 40 & 13.33 \\
\hline 7 & Other fruits & Yes & 13 & 4.33 \\
\hline 8 & Organ meat & Yes & 2 & 0.66 \\
\hline 9 & Flesh meat & Yes & 5 & 1.66 \\
\hline 10 & Eggs & Yes & 17 & 5.66 \\
\hline 11 & Fish & Yes & 2 & 0.66 \\
\hline 12 & Pulses & Yes & 130 & 43.33 \\
\hline 13 & Nuts and seeds & Yes & 25 & 8.33 \\
\hline 14 & Dairy & Yes & 153 & 51 \\
\hline 15 & Oils and fat & Yes & 134 & 44.66 \\
\hline 16 & Sweets & Yes & 39 & 13 \\
\hline 17 & $\begin{array}{l}\text { Condiments and } \\
\text { seasonings }\end{array}$ & Yes & 161 & 53.6 \\
\hline 18 & Other beverages & Yes & 221 & 73.6 \\
\hline
\end{tabular}


Based on the assumptions, the average household food insecurity access scale ranged from 0 to 27 . The percentage of households categorized as food secured, mild food insecure, moderately food insecure and severely food insecure were summarized (Table 19). The total sum of the positive responses for the 9 food insecurity indicators was 5062 for 300 households and the average was 16.9 which fall in severe food insecure category. About 37\%,21\% and 11\% of households were severe food insecurity, moderately food insecurity and mild-food insecurity respectively. About 31 percent was food secure. The maximum point of the figure was 24 and the minimum was 5 representing extremely severe food insecurity and food security respectively. Only three households had 24 values while only two households had 5 values.

Table 19. Food security status of households

\begin{tabular}{lllll}
\hline $\begin{array}{l}\text { Range of } \\
\text { category }\end{array}$ & $\begin{array}{l}\text { Summation } \\
\text { response Q1 to Q } 9\end{array}$ & $\begin{array}{l}\text { Number of } \\
\text { households }\end{array}$ & Percent & Status of HFIAS \\
\hline 0 & 0 & 87 & 31 & Secured \\
1 up to 8 & 7 & 63 & 11 & Mild food insecure \\
9 up to 17 & 17 & 81 & 21 & Moderate food insecure \\
18 up to 27 & 25 & 69 & 37 & Severely food insecure \\
& Total & $\mathbf{3 0 0}$ & $\mathbf{1 0 0 \%}$ & \\
\hline
\end{tabular}

\section{CONCLUSION AND RECOMMENDATIONS}

\subsection{Conclusion}

The study was conducted in Boloso Sore, Damote Pulasa, Kindo Koyisha and Duguna Fango woredas of Wolaita zone to generate baseline data for the project "Building Resilience for rural communities in Wolaita through sustainable production, value addition and marketing of traditional crops" that could help monitoring and evaluation of project through the agreed indicators and to track progress against the baseline situation. Data were generated from 300 households which were selected by using systematic random sampling techniques from 20 kebeles of the four woredas. Structured and semi-structured questionnaire which were developed and commented by staffs of TDA was used. Training on the questionnaire was given to enumerators and their supervisors and the questionnaire was pretested to 
check for validity and reliability. Survey was conducted for 18 days ,March 2021 and data were inputted to Excel and transported to STATA software for analysis. In addition checklist questions were developed and Key Informant Interviews were made with zonal and four woredas agricultural and natural resource experts. Moreover, secondary data were collected from Wolaita zone, four woredas and reports and publications. Data were analyzed using descriptive statistics, Household Dietary Diversity Score, Food Insecurity Access Scale and narrations.

The findings indicated that average age of households was 42.5 years indicating that households are at active working age. However, dependency ratio was $85 \%$ indicating the potential of active force to feed one non-working force. The average family size was 7 which are greater than the national average of 4.3 and the regional average of 4.9. More than 50 percent of households did not attend formal education. The dominant livelihood strategy was crop production and the contributions from livestock and off farm activities were very limited. Traditional crops were more marketed (38.3\%) than major crops (33.6\%) produced. Almost all households did not use chemical fertilizers and pesticides for production of traditional crops except for ginger, taro and garlic. This means that traditional crops production was organic mainly using manure. Few farmers used a combination of conservation techniques such as mulching, compost and intercropping. However, they did not practice other conservation agriculture principles like minimum tillage, cover crops and crop rotation and for those who were practicing sustainable farming practices, lack of awareness, lack of training and burning of crop residues were mentioned as challenges. In all four woredas and zone, experts and technical staff critically knew names of traditional crops, their advantages and disadvantages. The entire four target woredas and Wolaita zone agricultural bureau did not have any strategy and plan to promote traditional crops despite understanding their advantages. Moreover, there was not institutional taskforce working on promotion of traditional crops despite there are some idea to initiate traditional crops through the environment and forest conservation departments. On average 6 food categories were consumed by households within 24 hours during the survey. About 37 percent, 21 percent and 11 percent were severely food insecure, moderately food insecure and mildly food insecure respectively whereas 31 percent were food secure.

\section{Recommendations}

Based on the findings, the following specific recommendations were made for fruitful implementation of the project.

- The average family size of 7 was greater than national average of 4.3 as well as regional average of 4.9 calling for inclusion of integrated family planning approach in line with project implementation.

- More than half of households did not attend formal education. This implies that for the project to be successful, it should closely work with these communities in creating awareness and supervision and monitoring them on regular basis.

- The study depicted that $78 \%$ of households did not practice conservation agriculture principles; therefore, to ensure sustainability of traditional crops and building resilience of target communities, the project has to focus on building capacity of target households on sustainable production techniques such as conservation agriculture, organic agriculture and soil and water conservation methods.

- About 58.7 percent of traditional crops marketing were done using back of women as transportation means. This implies that the project should also device strategy to lessen labor burden on women.

- Traditional crops are more market oriented than major crops produced. This is actually a good opportunity for the project and the project should use this opportunity and organize farmers in groups to add value to traditional crops and improve their livelihood.

- The contributions of off farm income to supplement the household livelihood were almost limited. Therefore, the project should look ways to identify off-farm income generating activities and integrate them into the project activities to visualize the impact of the project at the end of the project lifespan.

- Traditional crops are organically produced as they are produced using sustainable conservation system. The project should strengthen this by further production of the crops during dry season through groundwater use (dig holes) and as the organic products are mostly wanted in the international markets it is possible to export the valued added products of traditional crops.

- There is no strategy, no plan and no institutional taskforce established to promote traditional crops at zonal and woreda levels. This calls for mobilization of the various stakeholders in line

with promoting traditional crops to improve livelihoods and to sustainably conserve natural resources.

- The nutritional diversity consumed by households were very much limited and the effect is profound with children under the age of six years as more than half of the households had children under the age of six. The project should work side by side ways of improving nutritional diversity of households. 
- About 69 percent of the households were food insecure. There is a lot to work with this regards for the project to bring impact at the end of its lifespan.

\section{REFERENCES}

[1] Anaeto F.C., Asiabaka C.C., Nnadi F.N, Ajaero J.O, Aja O.O,Ugwoke F.O, Ukpongson M.U1, Onweagba

[2] A.E (2012). The role of extension officers and extension services in the development of agriculture in Nigeria. Wudpecker Journal of Agricultural Research Vol. $1(6), 180-185$.

[3] CIA (2020). https://www.cia.gov/the-world-factbook/countries/ethiopia/. Central Intelligence Agency CSA (2007). 2007 Population and Housing Census of Ethiopia. Central Statistical Authority, April 2012,

[4] Addis Ababa, Ethiopia.

[5] FAO 2015. Assessment of the world food security situation. Committee on World Food Security, 31st session, 23-26 May. FAO (Food and Agricultural Organization). Rome.

[6] FAO (2006). http://www.fao.org/family-farming/detail/en/c/285675/.

[7] FAO (1999). www.fao.org/3/aj224e/aj224e02a.pdf.

[8] FAO and UNDP (2002). Gender Differences in the Transitional Economy of Viet Nam. Published by the Food and Agriculture Organization and the United Nations Development Programme, Ha Noi, Viet Nam, August 2002. www.fao.org/3/AC685E/ac685e05.htm.

[9] Mario Herrero, Delia Grace, Jemimah Njuki and Nancy Johnson (2012). The Roles of Livestock in Developing Countries. animal 7(s1):1-16 DOI:10.1017/S1751731112001954. November 2012.

[10] Oduro-Ofori Eric, Aboagye Anokye Prince and Acquaye Naa Aku Elfreda (2014). Effects of Education on The Agricultural Productivity of Farmers in the Offinso Municipality. International Journal of Development Research, Vol. 4, Issue, 9, pp. 1951-1960, September, 2014.

[11] WZFEDD (2017). Wolaita Zone socio-economic Information. Wolaita Zone Finance and Economic Development Department, May 2019.

[12] WFP (2008). Emergency Food Security Assessment Handbook. World Food Program.

[13] Yazie Chanie, Lemma Zemedu and Tilaye Teklewold (2014). Farmers' Participation in Farmers Research Groups and Its Contribution on Their Income from Rice: Empirical Evidence from Rice Production System of Fogera District, Ethiopia. Journal of Economics and Sustainable Development. ISSN $2222-1700$ (Paper) ISSN 2222-2855 (Online) Vol.5, No.13, 2014.

\section{AUTHORS}

First Author - Derese balcha MSC in economics, Wolaita Sodo University, Ethiopia ; deresebalango@gmail.com Second Author - Mathewos chafa Msc rural development and planning, Wolaita Sodo University, Ethiopia ; mathewoschafa2021@gmail.com 